\title{
Constraints to Youths' involvement in Agricultural Production in Kwara State, Nigeria
}

\author{
Adekunle, O. A; Adefalu, L. L.*, Oladipo, F. O; Adisa, R. S and Fatoye, A. D \\ Department of Agricultural Extension and Rural Development, \\ University of Ilorin, Ilorin, Nigeria \\ * Corresponding author: adefalulateef@yahoo.com.
}

\begin{abstract}
The study examines the constraints to rural youth involvement in agricultural Production in Kwara State, Nigeria. A total of one hundred and twenty (120) respondents were selected using a multi-stage cluster random sampling technique. Ten school respondents each were selected from twelve farming communities in the area. The major constraints hindering youth participation in agriculture were identified as inadequate credit facility $(\bar{X}=2.883)$, lack of agricultural insurance (M.S= 2.667), poor returns to agricultural investment ( $\bar{x}=2.667)$, lack of basic farming knowledge $(\bar{X}=2.567)$ and lack of access to tractors and other farm inputs. The chi-square showed relationship between the constraints and inadequate credit facility $\left(x^{2}-7.12\right)$, as well as lack of basic farming knowledge $\left(x^{2}-7.48\right)$. The study recommended provision of credit facilities with less stringent procedures and resuscitation of Agricultural Training Centres across the State to enhance youth's participation in agriculture.
\end{abstract}

\section{INTRODUCTION}

The world is currently facing multiple problems of food scarcity, global warming (resulting in climate change) and low pricing of crude oil, culminating in global economic recession. Nigeria as a nation is not however insulated against this global crisis considering her position in crude oil exportation and grain importation alike. The World Bank reports that global food prices rose $83 \%$ over the last three years and the Food and Agriculture Organization cites $45 \%$ increase in their world food price index during the past nine months (Eric and Loren, 2008). Biofuels have also forced global food prices up by $75 \%$ for more than previously estimated. Grains have been diverted away from food to fuel. For example, over a third of U.S corn is now used to produce ethanol; about half of vegetable oil in Europe goes towards the production of bio diesel (Aditya, 2008).

The implication of this recent trend is that, developing countries like Nigeria whose economy rely solely on importation of grains, particularly rice, for the feeding of their teeming populations have to go back to the drawing board to formulate more pragmatic policies capable of turning the food production pendulum back to their side.

For sustainable agricultural development in Nigeria, there is an urgent need for a more rapid transformation from subsistence farming to a more commercialized one, involving the 
application of modern technology (Adisa, 2005). The agricultural future of most of the developing countries may be bleak if the bulk of the production efforts are left in the hands of aged subsistent farmers who presently constitute the major farming population. The productivity level of the aged farmers can not meet the food and fibre needs of the rapidly growing population and they will definitely phase out on the account of age (Cook, 1996).

The youth at present, constitute about $60 \%$ of Nigeria's population and have over the years made significant contributions to National Development (Vision 2010 report, 2005). Unfortunately, the present environment makes it even more difficult to explore their full potential in agricultural production in order to stimulate the interest of our youth in agricultural production; government has to put in place certain measures that will eliminate the associated constraints in the sector. Involvement of youth in agricultural production has suffered nationally in recent years especially in the rural areas (Russel, 2001). Despite the fast growing opportunities in this sector, it is alarming and quite incredible to see many rural youths opting out of farming in search of non-existed white-collar jobs in the cities, leading to unprecedented level of rural-urban migration. This is obviously a potent threat to the aspiration of government to achieve food security by 2010.

The over-all effect of this scenario is that more Nigerians are going hungry by today and resources that could be used to improve on our infrastructures are spent on importation of food into the country. There is therefore a compelling need to boost and sustain youth's interest and participation in agricultural production activities. A study of the constraints faced by youths in agriculture is a step is thus expedient. This study thus seeks to provide answers to the following research questions:

(1) What are the youth's socio-economic characteristics?

(2) What are the factors militating against youths in agricultural production?

\section{Objectives of the study}

The general objective of the study is to identify the constraints to youth involvement in agricultural production in Kwara State, Nigeria.

The specific objectives are to;

(1) Examine the youths socio-economic characteristics;

(2) Identify the factors militating against youth participation in agricultural production.

\section{Hypothesis of the study}

$\mathrm{H}_{\mathrm{O}}$ : There is no significant relationship between factors militating against youth and their involvement in agricultural production.

$\mathbf{H}_{\mathrm{A}}$ : There is significant relationship between factors militating against youth and their involvement in agricultural production.

\section{METHODOLOGY}

The study was carried out in Irepodun Local Government Area (LGA) of Kwara state, Nigeria. The LGA was purposively chosen from the 16 LGAs in the State on the basis of its vast arable land which supports the cultivation of wide varieties of crops (KWSG, 2007). The population for the study was all rural community based youth in Kwara State. Twelve villages were randomly 
selected out of the forty two villages in Irepodun Local Government Area. Ten respondents were randomly selected from each of the villages giving a total sample size of 120 respondents.

A structured questionnaire was used to elicit information from the respondents. Descriptive statistics involving the use of frequency percentages, mean scores and ranking order were used to analyze data. Chi-square analysis was used to test the stated hypothesis.

\section{Measurement of Variables}

Age of respondents was measured in years. Respondents were required to state their own career ambition and father's occupation. The perceived constraints to farming, which were identified during reconnaissance survey, were measured a statements on a 3-point Likert-type scale. Respondents were required to indicate their levels of agreement/disagreement with the statements and consequently scored. The three levels were: Agree (3) Undecided (2) Disagree (1). There were 17 constraints listed on the questionnaire. Therefore, the maximum possible score for a respondent was 51, while the minimum possible score was 17.

Participation in agricultural production was measured as the active participation in any or a combination of the following farming activities: pre-planting, post-planting, harvest and postharvest. Respondents were thus categorized into those who participated in none, one, two, or all the three activities.

\section{RESULTS AND DISCUSSION}

\section{Socio-economic Characteristics of Respondents}

As shown in Table 1, majority (73.3\%) of the respondents were between the ages of $15-17$ years, while $11.7 \%$ of them were between the ages of $18-20$. This implies that respondents were mainly youths, going by definition of youth as a person aged between 12 and 30 years by the Vision 2010 Report (2005). Table 1 also shows that $50.8 \%$ of the respondents were males while the remaining $48.2 \%$ were females. The sex distribution gave room for a balanced opinion from both sexes of the respondents. Also from Table 1, 20\% of the respondents wanted become lawyers, $13.3 \%$ chose teaching, $28.3 \%$ were to become Engineers while the remaining respondents choice were Military (3.3\%), farmers (10.0\%) Accountants (1.7\%) and $1.8 \%$ went for unspecified professions. The high preference for non-agricultural based professions could be traced to the youth perceived low lucrative of farming.

The Table also showed that, $20 \%$ of the respondents' fathers were into business, $38.3 \%$ traders, $3.3 \%$ farmers, and $36.7 \%$ were teachers. This implies that, very few of the respondents were from farming background and this might have affected their overwhelming choice of careers outside agriculture. 
TABLE 1: Socio-economic Characteristics of the respondents

\begin{tabular}{lcc}
\hline Variables & Frequency $(\mathbf{N})$ & Percentage (\%) \\
\hline Age (Years) & 8 & 6.7 \\
$<12$ & 14 & 11.7 \\
$12-14$ & 88 & 73.3 \\
$15-17$ & 10 & 8.3 \\
$18-20$ & 120 & 100.0 \\
Total & & \\
Sex & 61 & 50.8 \\
Male & 59 & 49.2 \\
Female & 120 & 100.0 \\
Total & & \\
Father's Occupation & 24 & 20.0 \\
Business & 46 & 38.3 \\
Trading & 4 & 3.3 \\
Farming & 44 & 36.7 \\
Teaching & 2 & 1.7 \\
Craftsman & 120 & 100.0 \\
Total & & \\
Career Ambition & 24 & 20.0 \\
Law & 16 & 13.3 \\
Teaching & 34 & 28.3 \\
Engineering & 12 & 10.0 \\
Farming & 26 & 21.7 \\
Medicine & 4 & 3.3 \\
Military & 2 & 1.7 \\
Accountancy & 2 & 1.7 \\
Undecided & 120 & 100.0 \\
Total & &
\end{tabular}

Source: Field Survey, 2008

\section{Perceived constraints to participation in agriculture among respondents}

Respondents identified a wide range of constraints they perceived to militate against their active participation in agricultural production activities. Table 2 revealed that inadequate credit facilities $(x=2.88)$, poor returns to agricultural investment $(x=2.67)$, lack of agricultural insurance for produce during glut period $(x=2.67)$ and lack of access to tractors and other farm inputs $(x=2.48)$ were the major constraints that have militated against respondents' active participation in agriculture. 
Journal of Agricultural Extension

Vol. 13 (1) June, 2009

TABLE 2: Constraints to Youth Involvement in Agriculture

\begin{tabular}{llll}
\hline S/No & Constraints & $\begin{array}{l}\text { Mean } \\
\text { Score }\end{array}$ & Ranking \\
\hline 1. & Non-lucrativeness & 2.033 & $14^{\text {th }}$ \\
2. & My parent will not allow & 1.867 & $17^{\text {th }}$ \\
3. & Lack of initial capital & 2.150 & $11^{\text {th }}$ \\
4. & Poor returns to investment & 2.667 & $2^{\text {th }}$ \\
5. & Lack of basic farming knowledge & 2.567 & $4^{\text {th }}$ \\
6. & People will think in illiterate & 2.283 & $9^{\text {th }}$ \\
7. & No incentives for farmers & 2.233 & $9^{\text {th }}$ \\
8. & No agricultural insurance & 2.667 & $2^{\text {nd }}$ \\
9. & Lack of access to tractors \& other farm inputs & 2.483 & $5^{\text {th }}$ \\
10. & Transportation problem & 1.967 & $15^{\text {th }}$ \\
11. & Inadequate credit facility & 2.883 & $1^{\text {st }}$ \\
12. & It is energy-sapping & 2.333 & $9^{\text {th }}$ \\
13. & No storage facilities & 1.933 & $16^{\text {th }}$ \\
14. & No ready market & 2.350 & $6^{\text {th }}$ \\
15. & No future in agriculture & 2.069 & $13^{\text {th }}$ \\
16. & Nigerian economy & 2.300 & $10^{\text {th }}$ \\
17. & Farmers are not respected & 2.10 & $12^{\text {th }}$ \\
\hline
\end{tabular}

Source: Field Survey, 2008

\section{Hypothesis Test Results}

Table 3 summarizes the results of the chi-square analysis used to test the stated hypothesis, which was to determine whether or not there were significant differences in the perceived constraints and participation in agricultural production among the respondents.

TABLE 3: Chi-square test of the relationship level of participation in farming and perceived constraints

\begin{tabular}{lccc}
\hline \multicolumn{1}{c}{ Constraints } & $\begin{array}{c}\text { Chi Square } \\
\text { Value }\end{array}$ & Probability & Decision \\
\hline Lucrativeness & 1.69 & 0.00 & $\mathrm{~S}$ \\
Parental consent & 0.19 & 0.65 & $\mathrm{NS}$ \\
Initial capital & 1.37 & 0.00 & $\mathrm{~S}$ \\
Returns on investment & 2.51 & 0.00 & $\mathrm{~S}$ \\
Basic farming knowledge & 7.48 & 0.00 & $\mathrm{~S}$ \\
People's perception of farmers & 1.34 & 0.00 & $\mathrm{~S}$ \\
Incentives for farmers & 1.48 & 0.00 & $\mathrm{~S}$ \\
Access to tractors \& other farm inputs & 1.89 & 0.00 & $\mathrm{~S}$ \\
Agricultural insurance & 0.25 & 0.93 & $\mathrm{NS}$ \\
Transportation problem & 2.86 & 0.00 & $\mathrm{~S}$ \\
Credit facility & 7.12 & 0.00 & $\mathrm{~S}$ \\
Drudgery & 2.82 & 0.00 & $\mathrm{~S}$ \\
Storage facilities & 1.26 & 0.00 & $\mathrm{~S}$ \\
Market availability & 4.93 & 0.00 & $\mathrm{~S}$ \\
Future of agriculture & 1.06 & 0.00 & $\mathrm{~S}$ \\
Respect for farmers & 1.71 & 0.00 & $\mathrm{~S}$ \\
\hline
\end{tabular}

$S=$ Significant $;$ NS $=$ Not Significant Significance level $=0.05$

Source: Field Survey, 2008 
Table 3 reveals that, at 0.05 level of significance, nearly all the constraints had significant relationship with level of participation in agricultural production activities among respondents. Indeed, only two (agricultural insurance and parental consent) out of the sixteen constraints were not significantly related to the levels of participation in farming among respondents. Parental consent was not a significant factor perhaps due non-interference by parents of respondents on the participation in agriculture among their wards. Similarly, the non-significance of 'agricultural insurance' as a perceived constraint to respondents' level of participation in farming activities might be due to relative unpopularity of agricultural insurance in the study area. However, the significance relationship between level of participation in agricultural production and the other listed constraints suggests that the level of participation in agriculture among youths in the study area is still beleaguered with a lot of constraints.

\section{CONCLUSION AND RECOMMENDATIONS}

Identification of constraints in the involvement of youths in agricultural production has become for future food security. Based on the findings of this study, there is convincing rationale to conclude that much still need to be done to enhance youth's active participation in agricultural production. This study has identified inadequate credit facilities, low returns to agricultural investment, lack of access to tractors and other farming inputs as the major impediments. Other factors perceived as constraints by respondents include public perception of farmers, lack of basic knowledge of modern farming techniques. All these problem areas must be looked into in order to encourage greater participation of youth in agricultural production. Specifically, the study recommends the following as policy implications:

(1) Enhancement of youth's knowledge of basic farming activities through establishment of new Agricultural Training Centers and strengthening of existing ones. Also, Agricultural Science should be made compulsory among secondary school students to boost knowledge of agriculture among youths,

(2) Provision of credit facilities for youths in agriculture through micro-finance and rural commercial banks, and

(3) Changing of people's negative perceptions toward farming through proper orientation and public education. 


\section{Journal of Agricultural Extension}

Vol. 13 (1) June, 2009

\section{REFERENCE}

Adisa, R. S. (2005). Zimbabwean Farmers and the Future of Agriculture in Kwara State, The Herald, $18^{\text {th }}$ February, 2005

Aditya, C. (2008): Secret Report: Bio fuel caused food crisis, Internal World Bank study delivers blow to plant energy drives. The Guardian July 4, 2008.

Cook, Y. F. (1996): Summary of paper on Extension and Rural Youth Programme in Selected Countries.

Eric, H. G and Loren, P (2008): From food Rebellions to Food Sovereignty: Urgent Call to Fix a Broken Food System, Institute for Food and Development Policy, May, 162006.

Kwara State Government (2007) Kwara State Diary, 2007 Pp.12-22

National Population Commission (NPC), (1991): Report of 1991 Census, Lagos, Nigeria.

Russell, E. B. (2001): Attracting Youths to Agriculture. University of Illinois - Urbana Champaign pg. 1-4.

Vision 2010 report (2005): Youth, Development and Empowerment. 